ARTICLE OPEN

\title{
Oscillations in deep-open-cells during winter Mediterranean
}

\section{cyclones}

\author{
Huan Liu ${ }^{1,2}$, Ilan Koren $\mathbb{D}^{1 凶}$, Orit Altaratz $\mathbb{D}^{1}$, Reuven H. Heiblum ${ }^{1}$, Pavel Khain ${ }^{3}$, Xiaoran Ouyang ${ }^{1,4}$ and Jianping Guo $\mathbb{D}^{2}$
}

Open cloud cells can be described in ideal form as connected clouds that surround spots of isolated clear skies in their centers. This cloud pattern is typically associated with marine stratocumulus (MSc) that form in the oceanic boundary layer. However, it can form in deeper convective clouds as well. Here, we focus on deep-open-cells (with tops reaching up to $\sim 5-7 \mathrm{~km}$ ) that form in the postfrontal regions of winter Mediterranean cyclones, and examine their properties and evolution. Using a Lagrangian analysis of satellite data, we show that deep-open-cells have a larger equivalent diameter $(\sim 58 \pm 18 \mathrm{~km})$ and oscillate with a longer periodicity $(\sim 3.5 \pm 1 \mathrm{~h})$ compared to shallow MSc. A numerical simulation of one Cyprus low event reveals that precipitation-generated convergence and divergence dynamic patterns are the main driver of the open cells' organization and oscillations. Thus, our findings generalize the mechanism attributed to the behavior of shallow marine cells to deeper convective systems.

npj Climate and Atmospheric Science (2021)4:12; https://doi.org/10.1038/s41612-021-00168-9

\section{INTRODUCTION}

The classic Rayleigh-Bénard convection ${ }^{1,2}$ describes a fluid flow between two plates due to a uniform temperature gradient (heated from below). Gradual increase in the thermal forcing initially drives 2D roll pattern formation ${ }^{2}$ or $3 D$ hexagons ${ }^{3}$, which can then evolve into time-dependent flow, and finally into turbulent convection ${ }^{4}$. These dynamics are recognized in the atmosphere, especially over the ocean, by certain roll-like and hexagonal cloud patterns ${ }^{5-7}$. In the subtropical marine atmosphere, for example, heat from the ocean surface (the warmer plate) is transferred by convection to the boundary layer top (the colder upper plate), and shallow clouds organize into cloud streets (rolls and linear clouds) or cellular patterns (marine stratocumulus, MSc) that generate hexagonal shapes in their ideal form ${ }^{8}$. These clouds cover large oceanic regions, and have a significant effect on the earth's albedo and the transfer of heat, moisture and momentum in the lower atmosphere ${ }^{9,10}$. Cellular patterns of clouds can appear as closed or as open cells. Updraft that forms at the central part of the closed cell creates shallow clouds with large coverage, whereas for open cells the updraft forms along the cell's walls, yielding thicker clouds with lower cloud coverage ${ }^{11}$.

Although the general patterns of the Rayleigh-Bénard convection can provide a first-approximation description of cloud patterns, it is far too simple to capture the full complexity of cellular clouds' convection. A cloud field system is controlled by interactions and competitions between thermodynamic, radiative, and microphysical processes, and therefore forms a much richer physical system. For example, in MSc cloud fields the air mass properties and the boundary conditions are non-uniform ${ }^{9,12}$. The presence of the clouds in the system dictates a two-phase (at least) problem, including additional cloud processes ${ }^{13}$ and interactions with ambient meteorological conditions ${ }^{14}$.

The complexity of the cloud system leads to some discrepancies between the classical Rayleigh-Bénard theory and observations. For example, previous measurements of MSc cells reported a typical aspect ratio (diameter divided by depth) of $\sim 20^{6,8}$, while the theoretical value for Rayleigh-Bénard cells is between 1 and $3^{9}$. Other studies highlighted the crucial role of rain in impacting the dynamic and thermodynamic conditions, and hence the organization and evolution of MSc cells. For example, the evaporation of raindrops below cloud base generates a dynamic response of cellular organization of updrafts and downdrafts that promotes the formation of open cells ${ }^{15}$. Therefore, rain produced downdrafts, can open closed cells by flipping their dynamic circulation ${ }^{16-18}$. Other studies showed that precipitating MSc cells oscillate with an average periodicity of $\sim 3 \mathrm{~h}$, while closed ones (which don't precipitate) do not oscillate, and can maintain a steady structure for much longer ${ }^{17,19}$. On the other hand, there were studies that suggested that cold pool dynamic forcing is not essential for the organization of a cloud layer ${ }^{20,21}$.

Differently from shallow MSc cells (top at $1-2 \mathrm{~km}$ ), there are open cells that form under deeper convection conditions (refer hereafter as "deep-open-cells", up to 5-7 km). One example, which was rarely investigated, is deep-open-cells within the cold post-frontal sector of winter Mediterranean cyclones. Rosenfeld observed that these deep-open-cells are common within Cyprus lows (Mediterranean cyclones centered near Cyprus) ${ }^{22}$. Other studies that explored other areas around the global (like the northeast gulf of Alaska) revealed that similar deep-open-cells (cloud top up to $\sim 5.5 \mathrm{~km}$ ) are mostly a cold-season phenomenon $^{23}$, usually produce significant precipitation ${ }^{24}$, and are linked to squall-like patterns of the surface winds ${ }^{25}$. Again, like in the MSc case, cold pools were suggested as a primary agent of clouds' selforganization, in both observations and simulations ${ }^{23-27}$.

Here, we focus on deep-open-cells within winter Mediterranean cyclones. Those cyclones pass over the warm sea, transporting cold air from eastern Europe. The air mass becomes moist and unstable $e^{28}$, thus, cloud streets and open cells can form and produce specific rain patterns, which influence the local rainfall significantly ${ }^{29-31}$.

The goal of this work is to perform a detailed spatial and temporal analysis of deep-open-cells attributed to these winter

\footnotetext{
Department of Earth and Planetary Sciences, Weizmann Institute of Science, Rehovot, Israel. ${ }^{2}$ State Key Laboratory of Severe Weather, Chinese Academy of Meteorological Sciences, Beijing, China. ${ }^{3}$ Research and Development Department, the Israeli Meteorological Service, Beit Dagan, Israel. ${ }^{4}$ Department of Atmospheric Physics, Nanjing University of Information Science and Technology, Nanjing, China. ${ }^{凶}$ email: ilan.koren@weizmann.ac.il
} 
systems using observations, reanalysis data, and numerical modeling, to explore their characteristics.

\section{RESULTS AND DISCUSSION}

\section{Frequency of occurrence of deep-open-cells}

The frequency of occurrence, of deep-open-cells, within winter Mediterranean cyclones (between October to next March), was studied during the last 19 years (2002-2020), using the Moderateresolution Imaging Spectroradiometer (MODIS) RGB images and cloud top height $(C T H \geq 4.8 \mathrm{~km}$, see details in Supplementary Notes and Supplementary Fig. 1). The analysis results show that in $\sim 0.4$ to $\sim 0.6$ of those cyclonic days (per month) deep-open-cells were detected.

\section{Size and oscillations of deep-open-cells}

Our work is based on analysis of deep-open-cells' characteristics, in post-frontal activity of 13 winter Mediterranean cyclones (one case per year, using the Meteosat Second Generation-MSG measurements dataset, 2008-2020). First, we focus here on one case study, for demonstrating our methods in detail. This cyclone that originated above the North Atlantic Ocean on 20 January 2018, moved southeastward into the Mediterranean Sea, and intensified near the island of Cyprus during 24-26 January 2018 (a Cyprus low). On 26 January 2018, well-organized cloud streets and precipitating open cells developed in the cold sector, as captured by satellite observations (see details in Supplementary Notes and Supplementary Fig. 2). The sea level pressure was lower than 1007 $\mathrm{hPa}$ at the center of the low (at 06:00 UTC).

Figure 1a presents a High Resolution Visible (HRV) image from 26 January 2018 at 05:59 UTC, which clearly shows cloud structures of streets (south-east of Cyprus), and open cells (over a large region of the eastern Mediterranean). Using the identification method (see details in the Methods section below), 40 open cells were identified in the image (marked by red lines). The meteorological conditions that induced the formation of these cloud patterns were examined using the reanalysis data. Figure $1 \mathrm{~b}$ presents vertical cross-sections of the vertical pressure velocity (colors) and relative humidity $(\mathrm{RH}$, denoted by the black contours) along latitude $33^{\circ} \mathrm{N}$. The $\mathrm{RH}=50 \%$ contour is highlighted by the magenta line in Fig. $1 \mathrm{~b}$, as it serves as a proxy for

(a) 05:59 UTC
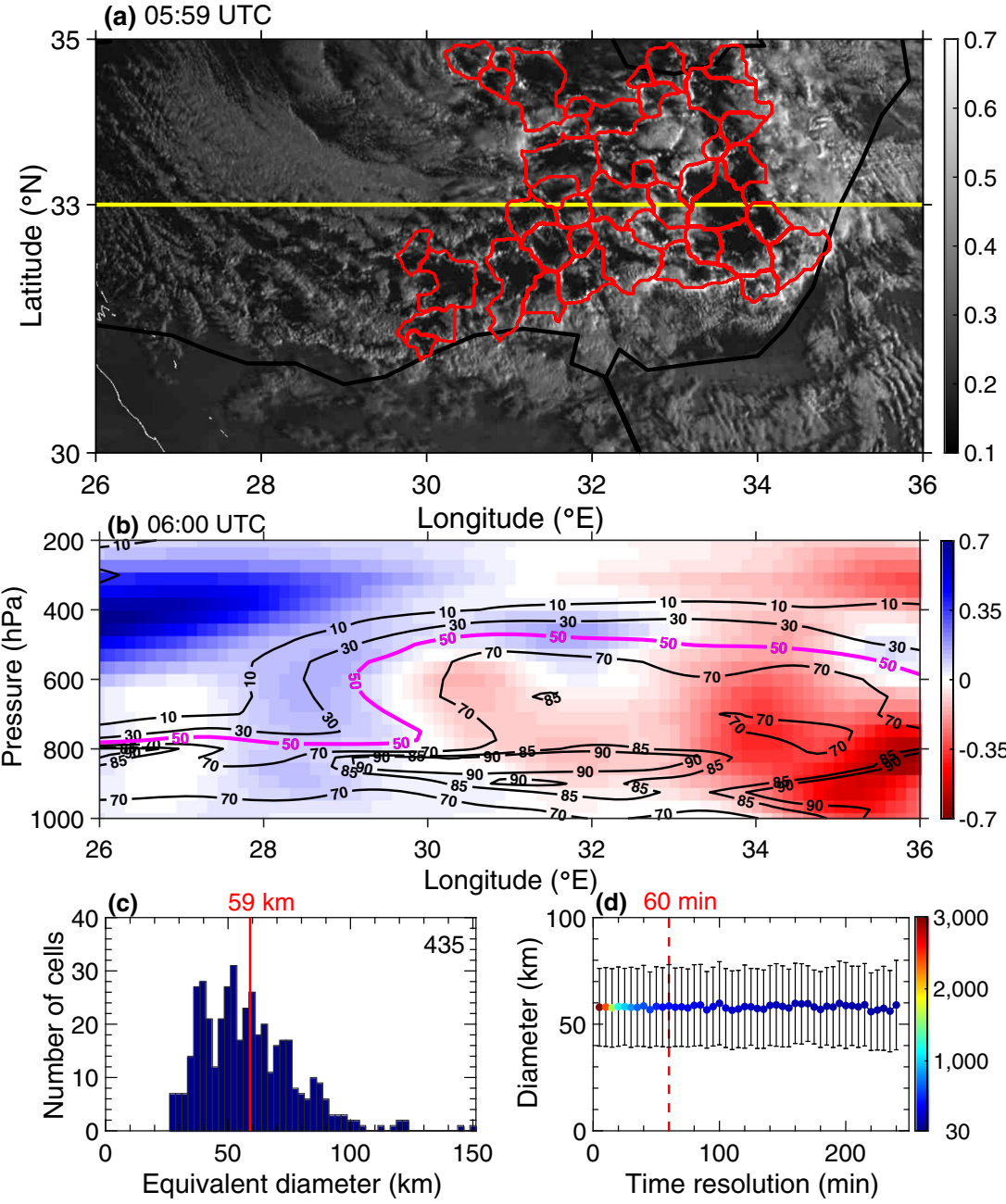

Fig. 1 Deep-open-cells in a Cyprus low event (26 January 2018). a 05:59 UTC, normalized reflectance image (HRV, color bar), the boundaries of the identified open cells are marked by the red lines. The thick black line indicates the coast. b 06:00 UTC, reanalysis ERA-interim data, presenting the vertical velocity in $\mathrm{Pa} \mathrm{s}^{-1}$ (color bar), and $\mathrm{RH}$ in \% vertical cross-section (black contours) along $33^{\circ} \mathrm{N}$ (yellow line in panel a). The magenta contour marks $\mathrm{RH}=50 \%$. c Histogram of open cells' equivalent diameter based on the HRV images at 05:59, 06:59, 07:59, 08:59, 09:59, 10:59, 11:59, 12:59, and 13:59 UTC. The red line indicates the average diameter $(59 \mathrm{~km})$. The black number at the top right indicate the total number of samples (435). d The average diameter of open cells as a function of sampling time (from 5 to 240 min, in 5 min intervals). The colors denote the number of samples, the error bars represent \pm 1 standard deviation, and the dashed red line marks the sampling time presented in panel c $(1 \mathrm{~h})$. 
(a) 07:29 UTC

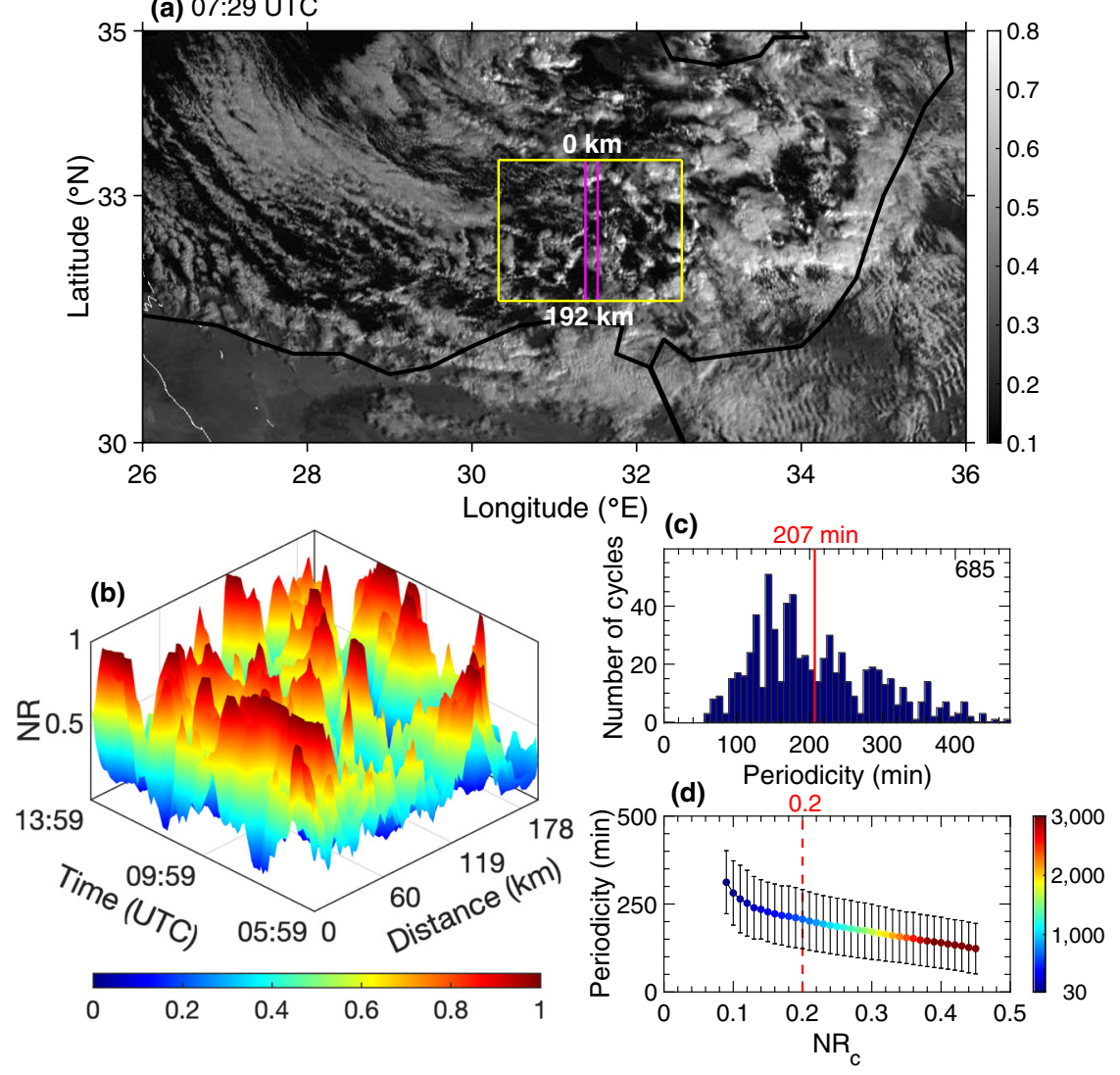

Fig. 2 Evolution of deep-open-cells (26 January 2018). a 07:29 UTC, normalized reflectance image (HRV, color bar). The yellow box marks the region of interest (ROI). Black thick lines mark the coast. The scale of distance (in magenta, 0 and $192 \mathrm{~km}$ ) marks the direction of the $x$-axis in panel (b). b Evolution of the cross-sections' normalized reflectance (NR, both the Z-axis and the colors), averaged over the central narrow strip (bounded by magenta lines in panel (a)). c Histogram of estimated periodicity of deep-open-cells over the ROI. The red line indicates the average value (207 $\mathrm{min}$ ). The black number at the top right indicates the total number of samples (685). $\mathbf{d}$ Average periodicity for deep-opencells as a function of the critical normalized reflectance ( $N R_{c}$ ) (from 0.05 to 0.45 , in 0.01 intervals). The colors denote the number of samples, the error bars represent \pm 1 standard deviation, and the dashed red line marks the $\mathrm{NR}_{\mathrm{c}}=0.2$, used in panel (c).

the inversion base height, and hence indicates the cloud top height (Fig. 3c, used for comparison with modeling results). A lowlevel inversion is observed on the west side of the cross-section (at $\sim 800 \mathrm{hPa} ; 2 \mathrm{~km}$ ), with a subsidence of dry air above it, while the east side shows a much deeper convective boundary layer, reaching up to $\sim 500 \mathrm{hPa}(5.5 \mathrm{~km})$. The analysis shows that the observed cloud streets were formed within a relatively shallow convective layer, while the open cells developed in a much deeper convective layer.

Figure 1c shows a histogram of equivalent diameters (obtained by converting each cell's area into the surface area of an equivalent circle) of the deep-open-cells observed in the HRV images, at 1-h intervals (to minimize cells' re-sampling), between 05:59 and 13:59 UTC. In total, 435 open cells with an average equivalent diameter of $\sim 59 \pm 19 \mathrm{~km}$ were detected. The cell sizes are in good agreement with previous studies, in which the sizes of open cells during Cyprus lows ranged between 40 and $80 \mathrm{~km}^{22}$. The sensitivity of the mean size to the corresponding sampling time (1 $\mathrm{h}$ for Fig. 1c) was tested in Fig. 1d. Note that in order to ensure meaningful statistics, only bins with at least 30 samples were analyzed ${ }^{32}$. Similar average diameters for various sampling times suggest low sensitivity and robust results.

To explore the evolution of deep-open-cells, we selected a small region of interest (ROl; yellow box in Fig. 2a). A Lagrangian tracking analysis was performed (see Methods section for details). Normalized reflectance (NR, colors) values were averaged between 05:59 UTC and 13:59 UTC (Fig. 2b), over the central narrow strip $(\sim 15 \mathrm{~km}$ in width and $\sim 192 \mathrm{~km}$ in length, marked by the magenta lines in Fig. 2a). The wave pattern in the NR suggests an oscillating behavior of the deep-open-cells (i.e., continuous alternations between the cloud-free inner cell and the cloudy cell walls; see details in Supplementary Notes and Supplementary Fig. 3).

The oscillation periodicities shown in Fig. $2 b$ are analyzed in Fig. 2c. The estimation is based on a critical NR value $\left(N R_{c}\right)$, where clear, transform, and cloudy areas are defined as pixels with relatively small $\left(\leq N R_{c}\right)$, moderate (from $N R_{c}$ to $\left.1-N R_{c}\right)$, and large $\left(\geq 1-N R_{c}\right) N R$ values, respectively. Accordingly, the periodicity was estimated as the time between two adjacent peak reflectance values (for cloudy areas), while both transform and clear areas were observed between the two peaks. Figure $2 \mathrm{c}$ shows the histogram of estimated periodicity with $\mathrm{NR}_{\mathrm{c}}=0.2$. 685 periodicity times were identified, with an average value of $\sim 3.5 \pm 1.4 \mathrm{~h}$. The sensitivity of the mean periodicity to the corresponding $\mathrm{NR}_{\mathrm{c}}(0.2$ for Fig. 2c) was tested in Fig. 2d. Again, bins with less than 30 samples were not analyzed ${ }^{32}$. As expected, the average periodicity decreased along with increasing $N R_{c}$. We chose $N R_{c}$ to be 0.2 , following the results obtained by satellite observations (see details in Supplementary Notes and Supplementary Fig. 3).

The same analysis was conducted for 12 additional cases using a sampling time of $1 \mathrm{~h}$ and $\mathrm{NR}_{\mathrm{c}}$ of 0.2 (see details in Supplementary Notes, Supplementary Fig. 4 and Supplementary Table 1). The detected open cells had an average equivalent diameter range of $\sim 54$ to $\sim 60 \mathrm{~km}$, and an oscillating average periodicity of $\sim 3$ to $\sim 4 \mathrm{~h}$. It suggests that deep-open-cells are larger and have longer oscillating periodicities compared to the 
corresponding values reported in the literature for MSc open cells (typical sizes of $10-50 \mathrm{~km}^{9,33}$ and periodicity of $\sim 3 \mathrm{~h}^{17,19}$ ).

\section{Numerical simulation of a Cyprus low event}

For further exploration of the obtained results, we simulated a Cyprus low event, which took place from 22:00 UTC on 23 January 2018 until 04:00 UTC on 27 January 2018, using the Consortium for Small-scale Modeling (COSMO) model (see details in the Methods section).

Figure 3 shows the simulation results for 06:00 UTC on 26 January. The simulated total water path $\left(\geq 10 \mathrm{~g} \mathrm{~m}^{-2}\right.$, presented in Fig. 3a), Mean Sea Level Pressure (MSLP, magenta contours in Fig. $3 a)$, total water content $\left(\geq 0.01 \mathrm{~g} \mathrm{~kg}^{-1}\right.$, colors in Fig. $\left.3 \mathrm{c}\right)$ and $\mathrm{RH}=$ $50 \%$ (magenta contours in Fig. 3c) exhibit similarities to the observational results (presented in Fig. 1 and Supplementary Fig. 2). Figure $3 \mathrm{~b}$ presents the surface wind divergence values, serving here as a proxy of the dynamic patterns, where negative values represent convergence (usually indicating updrafts, marked by the red shades), and positive values represent wind divergence (indicating downdrafts, shades of blue). Regarding the cloud patterns, the COSMO results show that shallow cloud streets (top at $\sim 800 \mathrm{hPa}$ ) with roll-like surface wind convergence occurred over the west side of the domain, while less organized deep-opencell structures (top at $\sim 500 \mathrm{hPa}$ ) with cell-like surface wind convergence developed in the east side.

The green contours in Fig. 3b mark the areas with a significant precipitation rate (surface rain rate $\geq 1 \mathrm{~mm} \mathrm{~h}^{-1}$ ). The consistency of these rain events and the cell-like surface wind divergence patterns point to rain driven cold pools formation ${ }^{25}$. The results suggest that rain is the main mechanism in organizing deep-opencell structures, similar to what was previously observed for shallow MSc open cells ${ }^{16-19}$.

To further explore the influence of precipitation-generated dynamic patterns on deep-open-cells' oscillations, we thoroughly examined the development of rain events and surface wind divergence. Figure 4 presents an example of nine snapshots of surface wind divergence obtained from the simulated results (see snapshots of cloud water path in Supplementary Fig. 5). The black
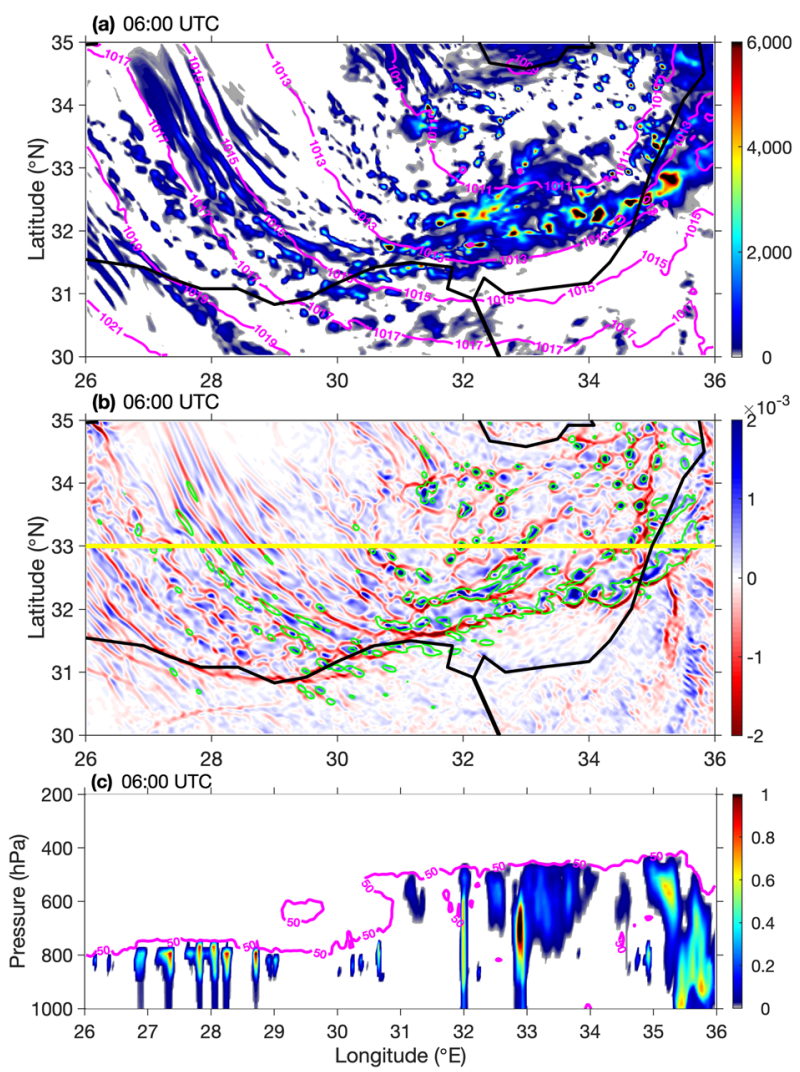

Fig. 3 COSMO simulation results (26 January 2018 at 0600 UTC) over the ROI (marked by the yellow box in Fig. 2a). a Map of total water path (color bar; unit: $\mathrm{g} \mathrm{m}^{-2}$ ) with MSLP (isobars, presented in 2 $\mathrm{hPa}$ intervals). b Map of surface wind divergence (color bar; unit: $\mathrm{s}^{-1}$ ) with surface rain rate $\geq 1 \mathrm{~mm} \mathrm{~h}^{-1}$ (green contours). Black thick lines in panel (a) and (b) mark the coast. c Total water content (color bar; unit: $\mathrm{g} \mathrm{kg}^{-1}$ ) vertical cross-section along $33^{\circ} \mathrm{N}$ (yellow line in panel (b)). The magenta line marks the $\mathrm{RH}=50 \%$.
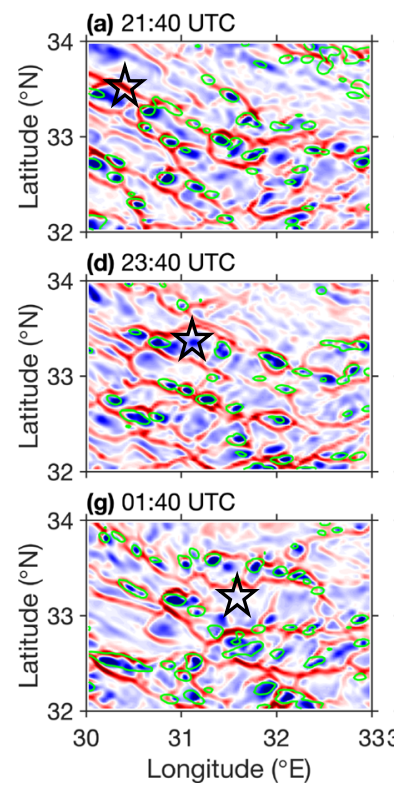

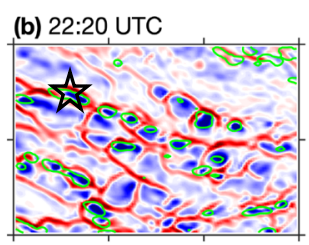

(e) 00:20 UTC

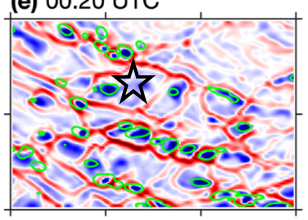

(h) 02:20 UTC

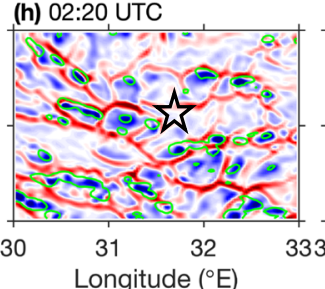

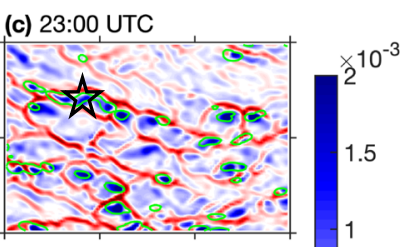

(f) 01:00 UTC

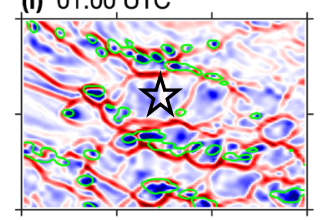

(i) 03:00 UTC

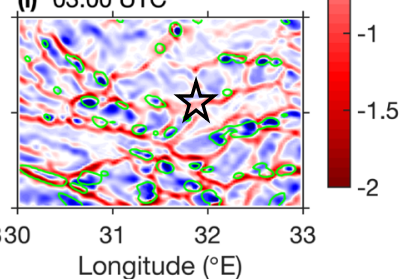

Fig. 4 Nine snapshots of surface wind divergence (color bar; unit: $\mathrm{s}^{-1}$ ) with surface rain rate of $1 \mathrm{~mm} \mathrm{~h}^{-1}$ (green contours). Obtained from COSMO simulations (between 25-26 January 2018, at 40-min intervals). The black stars mark the location of the tracked open cell, which is (a) located over a convergence boundary, corresponds to the middle cloud in Fig. 6 a. b Affected by significant precipitation, corresponds to Fig. 6 b. c-f Gradually turned into a divergence center, corresponds to Fig. $6 c$. g, h Affected by nearby rain events, corresponds to Fig. $6 \mathrm{~d}$. i Turned back into a convergence area, corresponds to Fig. 6 a. 


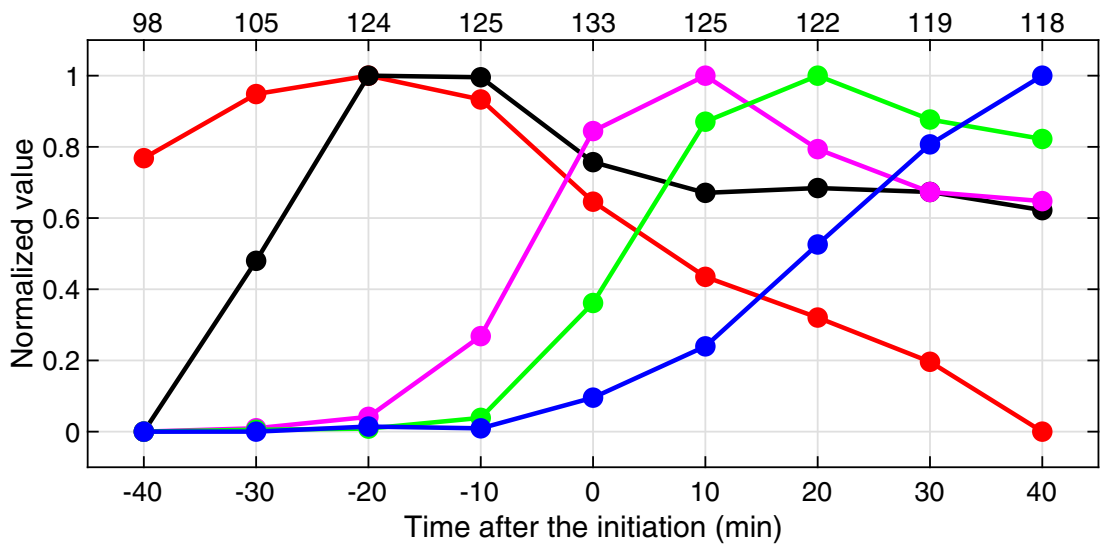

Fig. 5 Evolution of normalized averages of simulated parameters, over 133 rainy locations (in radius of $\sim \mathbf{~ k m}$ ). The red, black, magenta, green, and blue lines indicate the results for convergence, total cloud water path (liquid and ice), rain water content at the cloud base height, surface rain rate, and divergence, respectively. The number of analyzed events at each time (marked at the top $X$-axis) is not constant because events that could not be tracked properly were excluded from the analysis at each stage.

stars mark the evolution of one specific cell, to allow easy tracking (henceforth referred to as "star cell"). The first mark of the star cell (Fig. 4a) is located on the convergent boundary of a rain-induced cold pool (cloudy area, see Supplementary Fig. 5a). Then, significant precipitation begins (Fig. 4b), creating a new cold pool with a divergent center and convergent boundaries. Later on, with a larger rain area and spreading outflows (Fig. 4c-e), its divergent center expands dramatically, while its convergent boundaries are strengthened by encountering opposite outflows. At this stage, the cloudy area disappears and gradually becomes a cloud-free inner area, while new precipitating cloudy walls form over its convergent boundaries (Supplementary Fig. 5b-f). Afterward, the new rainy walls shrink the divergent center (Fig. $4 \mathrm{~g}, \mathrm{~h}$ ), turning it back into the convergent boundaries (Fig. 4i). As a result, the cloud-free inner region turns into the cloudy boundaries (Supplementary Fig. 5f-i).

To demonstrate the generality of our results, we tracked (by naked eyes) the evolution of 133 individual rain events in the simulated results. The initiation of each rain event was identified at the time of surface rain rate $\geq 1 \mathrm{~mm} \mathrm{~h}^{-1}$ (like marked by green contours in Fig. 4, weaker rain rates can appear before) and was set as time $=0$ (see Fig. 5). Then, we tracked the geometric center of each rain event for $1.5 \mathrm{~h}$ (40 min backward and $40 \mathrm{~min}$ forward from the initial time) and examined its surrounding clouds and dynamic structures along this time.

Figure 5 presents the results of those tracked rain events. It shows that the cloud water path (black line) develop following the convergence (red line). Then, rain falls below cloud base (magenta line) in clear convergence conditions (that fuel the cloud's updraft). Later rain reaches the surface (green line) and drives a divergence zone around it (blue line). The described sequence and how rain-caused outflows drive the alternations between divergence and convergence over a certain area (in a Lagrangian view) is well illustrated by Supplementary Movie 1.

The consistent results, as shown in Figs. 4-5, demonstrate the link between the produced rain and the convergence and divergence dynamic patterns. First, the onset of significant convergence sets the conditions for cloud formation. Once the cloud develops and starts to precipitate, the evaporation of rain below its base induces downdrafts that detach the cloud from the layer below. This cloud dissipation, induced by divergence in the surface, will be stronger for clouds that yield stronger rain. It is likely that this area will become the center of the next cycle of open cells. As shown by the schematic Figure (Fig. 6), such raincaused successive replacements between divergence and convergence patterns over a given area (followed by Lagrangian methods), yield alternating development of cloud-free and cloudy walls, and therefore appear as open-cell oscillating patterns.

Using observational and numerical modeling data, we studied the properties and evolution of deep-open-cells in the cold sector of 13 winter Mediterranean cyclones. We report here an average equivalent diameter of $\sim 58 \pm 18 \mathrm{~km}$ with a typical aspect ratio of $\sim 9\left(\sim 20\right.$ for $\left.\mathrm{MSc}^{6,8}\right)$. Lagrangian tracking analysis revealed that the cells' oscillate with an average periodicity of $\sim 3.5 \pm 1 \mathrm{~h}$ (longer than the estimated $\sim 3 \mathrm{~h}$ for $\mathrm{MSc}^{17,19}$ ). Numerical simulation of one case study of a Cyprus Low event (25-26 January, 2018) indicates that precipitation-generated surface wind divergence patterns are likely to be the driving process behind the oscillations of deepopen-cells.

Based on the current understanding of open cells, the findings in this paper reconfirm the importance of precipitation-generated dynamic patterns as a background mechanism for cellular fields' evolution. On one hand, such conclusions generalize the oscillating behavior of MSc cells ${ }^{17,19}$ to deeper systems, and both are related to rain events. On the other hand, larger cell size, and longer oscillating periodicity indicate a possible dependence of the cellular structures on the environmental conditions (such as winds, temperature, and humidity gradients). Further investigation will be needed for these open questions.

\section{METHODS}

\section{Data}

Three databases are used in this study: satellite observations, reanalysis data, and numerical simulations.

Satellite observations: To examine the properties of deep-open-cells during the 25-26 January 2018 event, we used HRV images, obtained along $8 \mathrm{~h}$ (05:59-13:59 UTC on 26 January 2018), with a temporal resolution of $5 \mathrm{~min}$, and a nadir spatial resolution of $1 \mathrm{~km}$. The images were obtained from the $\mathrm{MSG}^{34}$ satellite dataset and distributed by the European Organization for the Exploration of Meteorological Satellites [https:// www.eumetsat.int/website/home/index.html]. In a similar way, HRV images were used to analyze the 12 additional winter Mediterranean cyclones. Daily RGB images ${ }^{35}$ as measured by MODIS ${ }^{36}$, and $\mathrm{CTH}^{37}$, were used for examining the frequency of occurrence of deep-open-cells during the winter months (October-next March, 2002-2020). Rain rate as measured by the Global Precipitation Measure (GPM) Microwave Imager (GMI) ${ }^{38}$ was used in the Supplementary Information. [https://worldview.earthdata.nasa. gov].

Reanalysis data: Meteorological parameters were obtained from the European Centre for Medium-Range Weather Forecasts (ECMWF) ERAInterim dataset ${ }^{39}$, including vertical pressure velocity, RH, and MSLP (for the Supplementary Information only), with a horizontal resolution of $0.125^{\circ} \times 0.125^{\circ}$. Vertical pressure velocity and $\mathrm{RH}$ were retrieved at 


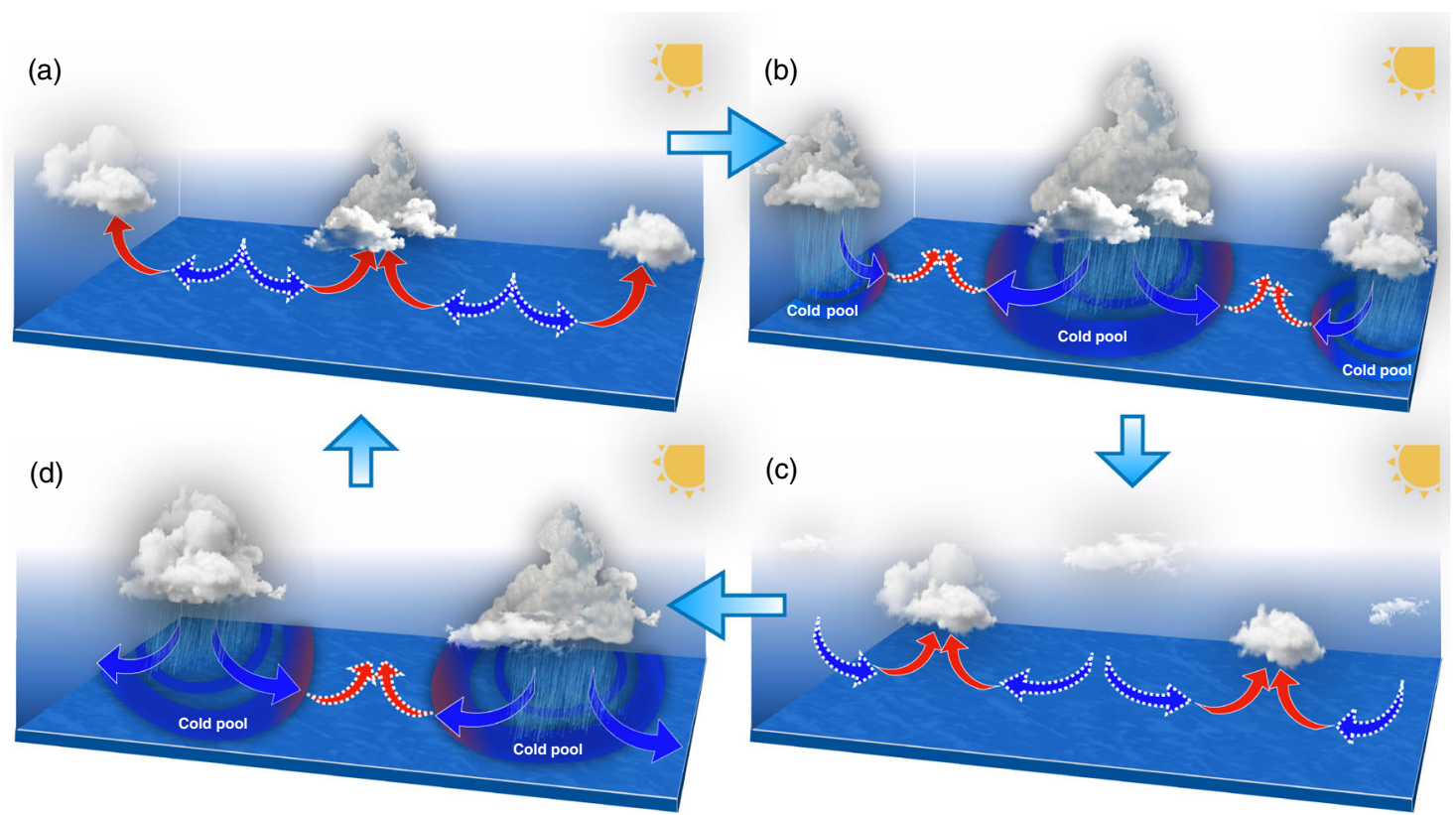

Fig. 6 Schematic description of the mechanism behind oscillating deep-open-cells. a Cloud walls form at open cell's boundaries. b Rain starts in deeper wall clouds and causes cold pools. c New clouds develop by the cold pool flow and form cloud walls for the new generated open cells. d New rain events by the mature wall clouds trigger a new oscillation cycle.

standard pressure levels between 1000 and $200 \mathrm{hPa}$ [https://apps.ecmwf. int/datasets/data/interim-full-daily/levtype $=\mathrm{sfc} / \mathrm{J}$.

Numerical simulations: To explore the physical mechanisms, a numerical simulation was conducted using the COSMO model ${ }^{40}$ [www.cosmo-model. org] for the period between 22:00 UTC on 23 January 2018 and 04:00 UTC on 27 January 2018. The simulated domain covered the eastern Mediterranean region $\left(25^{\circ} \mathrm{E}-39^{\circ} \mathrm{E}\right.$ and $\left.26^{\circ} \mathrm{N}-36^{\circ} \mathrm{N}\right)$ with a $0.025^{\circ}(\sim 2.5 \mathrm{~km})$ horizontal resolution ${ }^{41}$. The domain vertical extension was $23.5 \mathrm{~km}(\sim 30$ $\mathrm{hPa}$ ) with 60 levels of gradually increasing depth with height (between 20-1200 m). The boundary and initial conditions were taken from the ECMWF Integrated Forecasting System [www.ecmwf.int/en/forecasts/ documentation-and-support]. The COSMO model is based on the primitive thermo-hydrodynamic equations that describe non-hydrostatic compressible flow in a moist atmosphere ${ }^{40,42,43}$. A one-moment microphysical scheme was used to calculate the mass of cloud drops, rain, ice, snow, and graupel particles.

\section{Analysis methods}

The methods used to identify and track open cell cloud structure in HRV images are briefly introduced here.

For detecting open cell structures and their boundaries, we used a method that is based on a watershed morphological transformation. It was developed for identifying shallow cellular clouds, and has been tuned to be robust and consistent ${ }^{44}$. Gray scale satellite images were treated as a topographic surface with the gray levels corresponding to topographic height. Then the segmentation was performed by identifying watershed regions accordingly ${ }^{44}$. Considering that different cloud structures (e.g. cloud streets, open cells, and frontal cloud bands) may coexist in close proximity, we further limited the analyzed data to include only: i) groups of open cells (at least 4 cells per cluster), ii) cells that do not touch the image edges, and iii) cells with clear contrast between the cell walls and its inner region reflectance (i.e. inner-to-walls ratio $<0.75$ ).

For taking into consideration the background advection while tracking the open cells, we used the Lagrangian tracking analysis proposed by Koren and Feingold ${ }^{19}$. This method assumes that during a relatively short time interval ( $15 \mathrm{~min}$ in their study), a cloud field maintains its general structure (even if specific cloud features change within that time). Therefore, the similarity between consecutive satellite images enables detection of shifting due to advection. In other words, the advection can be determined by optimizing the similarity between two consecutive images ${ }^{19}$. Here, in order to focus on well-organized deep-open-cells, we performed the Lagrangian tracking analysis in both backward and forward manners using HRV images with a temporal resolution of $5 \mathrm{~min}$ (see example in Supplementary Notes and Supplementary Fig. 3).

\section{DATA AVAILABILITY}

All observational datasets and the COSMO model used in this study are publicly available (see websites in the methods section). COSMO simulated data and all the computer codes used to generate results are available upon request.

Received: 22 September 2020; Accepted: 1 February 2021; Published online: 02 March 2021

\section{REFERENCES}

1. Bénard, H. Les tourbillons cellulaires dans une nappe liquid. J. Phys. Theor. Appl. 10, 254-266 (1901).

2. Rayleigh, L. LIX. On convection currents in a horizontal layer of fluid when the higher temperature is on the under side. Lond. Edinb. Dubl. Philos. Mag. 32, 529-546 (1916).

3. Christopherson, D. G. Note on the vibration of membranes. Q. J. Math. 11, 63-65 (1940).

4. Chandrasekhar, S. Hydrodynamic and Hydromagnetic Stability (Oxford University Press, 1961).

5. Agee, E. M. \& Chen, T. S. A model for investigating eddy viscosity effects on mesoscale cellular convection. J. Atmos. Sci. 30, 180-189 (1973).

6. Agee, E. M. Observations from space and thermal convection: a historical perspective. Bull. Am. Meteorol. Soc. 65, 938-949 (1984).

7. Krueger, A. F. \& Fritz, S. Cellular cloud patterns revealed by TIROS I. Tellus 13, 1-7 (1961).

8. Agee, E. M. Mesoscale cellular convection over the oceans. Dyn. Atmos. Ocean 10, 317-341 (1987).

9. Atkinson, B. W. \& Wu Zhang, J. Mesoscale shallow convection in the atmosphere. Rev. Geophys. 34, 403-431 (1996).

10. Wood, R. et al. Open cellular structure in marine stratocumulus sheets. J. Geophys. Res. Atmos. 113, D12207 (2008).

11. Feingold, G., Koren, I., Yamaguchi, T. \& Kazil, J. On the reversibility of transitions between closed and open cellular convection. Atmos. Chem. Phys. 15, 7351-7367 (2015).

12. Kondo, H., Kimura, R. \& Nishimoto, S. Effects of curved temperature profiles on the Bénard-rayleigh convective instability. J. Meteorol. Soc. Jpn. 50, 65-69 (1972).

13. Sheu, P. J., Agee, E. M. \& Tribbia, J. J. A numerical study of physical processes affecting convective cellular geometry. J. Meteorol. Soc. Jpn. 58, 489-499 (1980). 
14. Slingo, A., Nicholls, S. \& Schmetz, J. Aircraft observations of marine stratocumulus during JASIN. Q. J. R. Meteorol. Soc. 108, 833-856 (1982).

15. Wang, H. \& Feingold, G. Modeling mesoscale cellular structures and drizzle in marine stratocumulus. Part I: impact of drizzle on the formation and evolution of open cells. J. Atmos. Sci. 66, 3237-3256 (2009).

16. Rosenfeld, D., Kaufman, Y. J. \& Koren, I. Switching cloud cover and dynamical regimes from open to closed Bénard cells in response to the suppression of precipitation by aerosols. Atmos. Chem. Phys. 6, 2503-2511 (2006).

17. Feingold, G., Koren, I., Wang, H., Xue, H. \& Brewer, W. A. Precipitation-generated oscillations in open cellular cloud fields. Nature 466, 849-852 (2010).

18. Stevens, B. et al. Pockets of open cells and drizzle in marine stratocumulus. Bull. Am. Meteorol. Soc. 86, 51-58 (2005).

19. Koren, I. \& Feingold, G. Adaptive behavior of marine cellular clouds. Sci. Rep. 3 1-5 (2013).

20. Zhou, X., Heus, T. \& Kollias, P. Influences of drizzle on stratocumulus cloudiness and organization. J. Geophys. Res. Atmos. 122, 6989-7003 (2017).

21. Zhou, X., Ackerman, A. S., Fridlind, A. M. \& Kollias, P. Simulation of mesoscale cellular convection in marine stratocumulus. Part I: drizzling conditions. J. Atmos. Sci. 75, 257-274 (2018).

22. Rosenfeld, D. Characteristics of Rainfall Cloud Systems, Radar and Satellite Images Over Israel (Hebrew University, 1980).

23. Sikora, T. D., Young, G. S., Fisher, C. M. \& Stepp, M. D. A synthetic aperture radar-based climatology of open-cell convection over the Northeast Pacific Ocean. J. Appl. Meteorol. Climatol. 50, 594-603 (2011).

24. Sikora, T. D., Wendoloski, E. B. \& Marter, R. E. A climatology of precipitating opencell convection over the northeast gulf of Alaska. J. Appl. Meteorol. Climatol. 53, 2843-2847 (2014).

25. Young, G. S., Sikora, T. D. \& Fisher, C. M. Use of MODIS and synthetic aperture radar wind speed imagery to describe the morphology of open cell convection. Can. J. Remote Sens. 33, 357-367 (2007)

26. Haerter, J. O., Berg, P. \& Moseley, C. Precipitation onset as the temporal reference in convective self-organization. Geophys. Res. Lett. 44, 6450-6459 (2017).

27. Fuglestvedt, H. F. \& Haerter, J. O. Cold pools as conveyor belts of moisture. Geophys. Res. Lett. 47, e2020GL087319 (2020).

28. Shay-El, Y. \& Alpert, P. A diagnostic study of winter diabatic heating in the Mediterranean in relation to cyclones. Q. J. R. Meteorol. Soc. 117, 715-747 (1991).

29. Peleg, N. \& Morin, E. Convective rain cells: radar-derived spatiotemporal characteristics and synoptic patterns over the eastern Mediterranean. J. Geophys. Res. Atmos. 117, D15116 (2012).

30. Saaroni, H., Halfon, N., Ziv, B., Alpert, P. \& Kutiel, H. Links between the rainfall regime in Israel and location and intensity of Cyprus lows. Int. J. Climatol. 30, 1014-1025 (2010).

31. Sharon, D. \& Kutiel, H. The distribution of rainfall intensity in Israel, its regional and seasonal variations and its climatological evaluation. Int. J. Climatol. 6 , 277-291 (1986)

32. Wilks, D. S. Statistical Methods in the Atmospheric Sciences (Academic Press, 2011)

33. Wood, R. \& Hartmann, D. L. Spatial variability of liquid water path in marine low cloud: the importance of mesoscale cellular convection. J. Clim. 19, 1748-1764 (2006).

34. Schmetz, J. et al. An introduction to Meteosat Second Generation (MSG). Bull. Am. Meteorol. Soc. 83, 977-992 (2002).

35. Gumley, L., Descloitres, J. \& Schmaltz J. Creating Reprojected True Color MODIS Images: a Tutorial. Technical Report Version 1.0.2. (University of WisconsinMadison, Space Science and Engineering Center, 2010).

36. Esaias, W. E. et al. An overview of MODIS capabilities for ocean science observations. IEEE Trans. Geosci. Remote Sens. 36, 1250-1265 (1998).

37. Platnick, S. et al. The MODIS cloud products: algorithms and examples from Terra. IEEE Trans. Geosci. Remote Sens. 41, 459-473 (2003).

38. Hou, A. Y. et al. The global precipitation measurement mission. Bull. Am. Meteorol. Soc. 95, 701-722 (2014).

39. Dee, D. P. et al. The ERA-Interim reanalysis: configuration and performance of the data assimilation system. Q. J. R. Meteorol. Soc. 137, 553-597 (2011).
40. Baldauf, M. et al. Operational convective-scale numerical weather prediction with the COSMO model: description and sensitivities. Mon. Weather Rev. 139, 3887-3905 (2011).

41. Khain, P. et al. Improving the precipitation forecast over the Eastern Mediterranean using a smoothed time-lagged ensemble. Meteorol. Appl. 27, e1840 (2020).

42. Kunz, M. et al. The severe hailstorm in southwest Germany on 28 July 2013: characteristics, impacts and meteorological conditions. Q. J. R. Meteorol. Soc. 144 231-250 (2018)

43. Steppeler, J. et al. Meso-gamma scale forecasts using the nonhydrostatic model LM. Meteor. Atmos. Phys. 82, 75-96 (2003).

44. Gufan, A. et al. Segmentation and tracking of marine cellular clouds observed by geostationary satellites. Int. J. Remote Sens. 37, 1055-1068 (2016).

\section{ACKNOWLEDGEMENTS}

This research has been supported by the Ministry of Science and Technology, Israel (Grant no. 3-14444).

\section{AUTHOR CONTRIBUTIONS}

I.K., O.A., H.L., and R.H.H. designed the study. H.L., R.H.H., and O.X. analyzed the observational and numerical data. P.K. conducted the numerical simulations. H.L., O. A., I.K., and J.G. wrote the manuscript. All co-authors provided critical feedback and helped shape the research, analysis, and manuscript.

\section{COMPETING INTERESTS}

The authors declare no competing interests.

\section{ADDITIONAL INFORMATION}

Supplementary information The online version contains supplementary material available at https://doi.org/10.1038/s41612-021-00168-9.

Correspondence and requests for materials should be addressed to I.K.

Reprints and permission information is available at http://www.nature.com/ reprints

Publisher's note Springer Nature remains neutral with regard to jurisdictional claims in published maps and institutional affiliations.

Open Access This article is licensed under a Creative Commons Attribution 4.0 International License, which permits use, sharing, adaptation, distribution and reproduction in any medium or format, as long as you give appropriate credit to the original author(s) and the source, provide a link to the Creative Commons license, and indicate if changes were made. The images or other third party material in this article are included in the article's Creative Commons license, unless indicated otherwise in a credit line to the material. If material is not included in the article's Creative Commons license and your intended use is not permitted by statutory regulation or exceeds the permitted use, you will need to obtain permission directly from the copyright holder. To view a copy of this license, visit http://creativecommons. org/licenses/by/4.0/.

(c) The Author(s) 2021 